\title{
Solubilization of Molecular Forms of Lysosomal Acid Phosphatase of Solanum tuberosum L. Leaves during Infection by Phytophthora infestans (Mont.) de Bary
}

\author{
By D. PITT \\ Department of Biological Sciences, The University, Exeter
}

(Received I I October 1972)

\begin{abstract}
SUMMARY
Density-gradient ultracentrifugation of potato-leaf extracts on a Ficoll gradient resolved a fraction containing membrane-bounded particles equilibrating at a density of $\mathrm{I} \cdot 095 \mathrm{~g} \mathrm{~cm}^{-3}$. The fraction was heterogeneous by electron microscopy and contained several particle types, some of which had single and double membranes, with diameters between $0.05 \mu \mathrm{m}$ and $\mathrm{I} \cdot 0 \mu \mathrm{m}$, along with amorphous cytoplasmic material and ER-derived elements. A peak of acid phosphatase activity was associated with the fraction, from which varying amounts of enzyme were released by freezing and thawing, osmotic shock and treatments with Triton $\mathrm{X}-\mathrm{IOO}$, snake venom and phospholipase A. Infection of leaves by Phytophthora infestans resulted in a massive transfer to the supernatant-fluid fraction of one molecular form of acid phosphatase which was particle-bound in the uninfected leaves.
\end{abstract}

\section{INTRODUCTION}

Infections of potato tubers and callus cells by Phytophthora erythroseptica Pethybr., Fusarium caeruleum (Lib.) Sacc. and Phytophthora infestans (Mont.) de Bary are accompanied by the release of acid hydrolases from a sedimentable to a soluble form (Pitt \& Coombes, 1968, 1969). However, the increased lysosomal enzyme activity in the supernatantfluid fractions of tissue extracts may be accompanied by activation of preformed enzyme (Pitt \& Galpin, 1973a), and consequently it is not clear if the soluble enzyme has arisen from a previously bound form within the host or parasite or through activation of an already soluble inactive form. The recent observations by Pitt \& Galpin (1973 $b$ ) showed differences in the molecular size of particulate and soluble forms of acid phosphatase in potato sprouts, which suggested a possible means of determining the origin of increased soluble enzyme activity arising during infection.

The present investigation was undertaken to determine if the increased activity of acid phosphatase occurring in the soluble fraction of potato leaves infected with potato late blight was derived from either the host-plant lysosomes, a soluble enzyme component of the host, or from the parasite.

\section{METHODS}

Organisms. Potato leaves cv. Majestic were obtained from plants grown in the glasshouse at $20^{\circ} \mathrm{C}$ under natural daylight during the months January to May. Phytophthora infestans, race $\mathrm{I}: 4$, was originally a gift from Professor N. F. Robertson and was maintained on green-bean agar (Ingram \& Robertson, 1965), with occasional passage through the host.

Preparation of homogenates and isolation of leaf lysosomes on Ficoll density gradients. Extraction medium consisted of $0.4 \mathrm{M}$-sucrose in $\mathrm{O} \cdot \mathrm{I}$ M-tris- $\mathrm{HCl}$ buffer, $\mathrm{pH} 7 \cdot \mathrm{I}$, containing I mM-EDTA, $\mathrm{O} \cdot \mathrm{I} \%$ cysteine hydrochloride, $0 \cdot \mathrm{I} \%(\mathrm{v} / \mathrm{v}) \beta$-mercaptoethanol and $2.5 \%(\mathrm{w} / \mathrm{v})$ 
Ficoll (Pharmacia Fine Chemicals AB, Uppsala, Sweden). Leaves were cooled to $4{ }^{\circ} \mathrm{C}$, chopped with a razor blade and ground by hand for $3 \mathrm{~min}$ in a pestle and mortar with $1 \mathrm{~g}$ sand at a rate of $15 \mathrm{~g}$ tissue in $30 \mathrm{ml}$ extraction medium. The extract was strained through two layers of cheesecloth and the liquid phase was centrifuged at $2000 \mathrm{~g}$ for $10 \mathrm{~min}$ to remove the larger debris. The turbid green supernatant was designated the crude lysosomal fraction. Density-gradient ultracentrifugation was carried out on linear gradients made from $3.5 \%$ and $28.5 \%(\mathrm{w} / \mathrm{v})$ solutions of Ficoll in extraction medium. Samples $(4.5$ to $5.0 \mathrm{ml})$ of crude lysosomal suspension were layered over the $18 \mathrm{ml}$ gradients, which were then centrifuged at $65000 \mathrm{~g}$ for $3 \mathrm{~h}$ in an M.S.E. Superspeed 65 ultracentrifuge at $2{ }^{\circ} \mathrm{C}$. Tubes were punctured using an M.S.E. tube-piercer fitted with a 22-gauge needle and 28 fractions of 30 drops each were collected from each of the three tubes and stored overnight at between 0 and $4{ }^{\circ} \mathrm{C}$ before assay.

Total enzyme activity of leaves was determined after homogenization in a high-speed tissue blender (M.S.E. 'Atomix') operating at full speed for 3 min at $4{ }^{\circ} \mathrm{C}$, and assaying the supernatant fluid fraction obtained after centrifugation of the extract at $38000 \mathrm{~g}$ for $30 \mathrm{~min}$ at $4{ }^{\circ} \mathrm{C}$. Enzyme extracts of the pathogen were prepared by similarly homogenizing mycelial mats of Phytophthora infestans harvested after growth for 7 days at $25^{\circ} \mathrm{C}$ on green-bean broth.

Treatments used to examine the stability of lysosomal fractions. The particulate fraction equilibrating at fractions 17 to 19 during ultracentrifugation experiments was subjected to the following treatments. (i) Freezing and thawing was done by the rapid immersion of samples in liquid nitrogen with thawing to between $\mathrm{o}$ and $4{ }^{\circ} \mathrm{C}$. The process was repeated three times to complete the treatment. (ii) Homogenization was carried out in an M.S.E. vortex homogenizer at full speed for $3 \mathrm{~min}$ at between $\mathrm{o}$ and $4{ }^{\circ} \mathrm{C}$. (iii) Ultrasonication was done for three $\mathrm{IO}$ s periods over intervals of $\mathrm{I}$ min at between $\mathrm{O}$ and $4{ }^{\circ} \mathrm{C}$ by using an M.S.E. ultrasonic disintegrator operating at full power. (iv) Triton $\mathrm{X}-100$ was added at a rate of $0.1 \%(\mathrm{v} / \mathrm{v})$ with mixing. (v) Osmotic shock was achieved by diluting fractions with $9 \mathrm{vol}$. of distilled water or with $0 \cdot \mathrm{I}$ M-tris- $\mathrm{HCl}$ buffer, $\mathrm{pH} 7 \cdot \mathrm{I}$. (vi) Crude venom from Crotalus adamenteus (Sigma Chemical Co. Ltd, London) was partially purified by the method of Bachmann, Allmann \& Green (1966) and lysosomal fractions were digested for I 5 min by using the procedure of Pitt \& Galpin (1973b). (vii) Phospholipase A (Boehringer, Mannheim, Germany) from Crotalus terrificus terrificus was used for digestion according to Pitt \& Galpin (1973b).

After the above treatments lysosomal suspensions were centrifuged at $105000 \mathrm{~g}$ for $30 \mathrm{~min}$ at $4{ }^{\circ} \mathrm{C}$ to give supernatant fluid (soluble) and particulate fractions.

Solubilization of lysosomal acid phosphatase with venom for gel-filtration experiments. This was done as above and the supernatant fluid fraction was subjected to gel filtration on Sephadex G-IOo according to Pitt \& Galpin (I973b).

Assays. (i) Acid phosphatase (EC 3.I .3.2) activity was determined by using $p$-nitrophenyl phosphate as the substrate as described by Pitt \& Galpin (I97I). Appropriate zero-time blanks were carried out and experiments were also done with reaction mixtures containing O.I M-sodium fluoride, $\mathrm{O}$. I M-L-tartrate, $5 \mathrm{mM}$-orthophosphate or $1 \mathrm{O}^{-5} \mathrm{M}$-ammonium molybdate. A unit of enzyme activity was that amount of enzyme liberating I $\mu \mathrm{mol}$ of $p$-nitrophenol/min under the conditions of the assay. Enzyme activity is expressed when possible as the specific activity, but where digests containing exogenous venom protein were used acid phosphatase activity is expressed per fraction of column eluate. In such instances comparability of results was achieved by digesting particle samples which contained equivalent amounts of protein. (ii) Soluble protein was determined by the method of Lowry, 


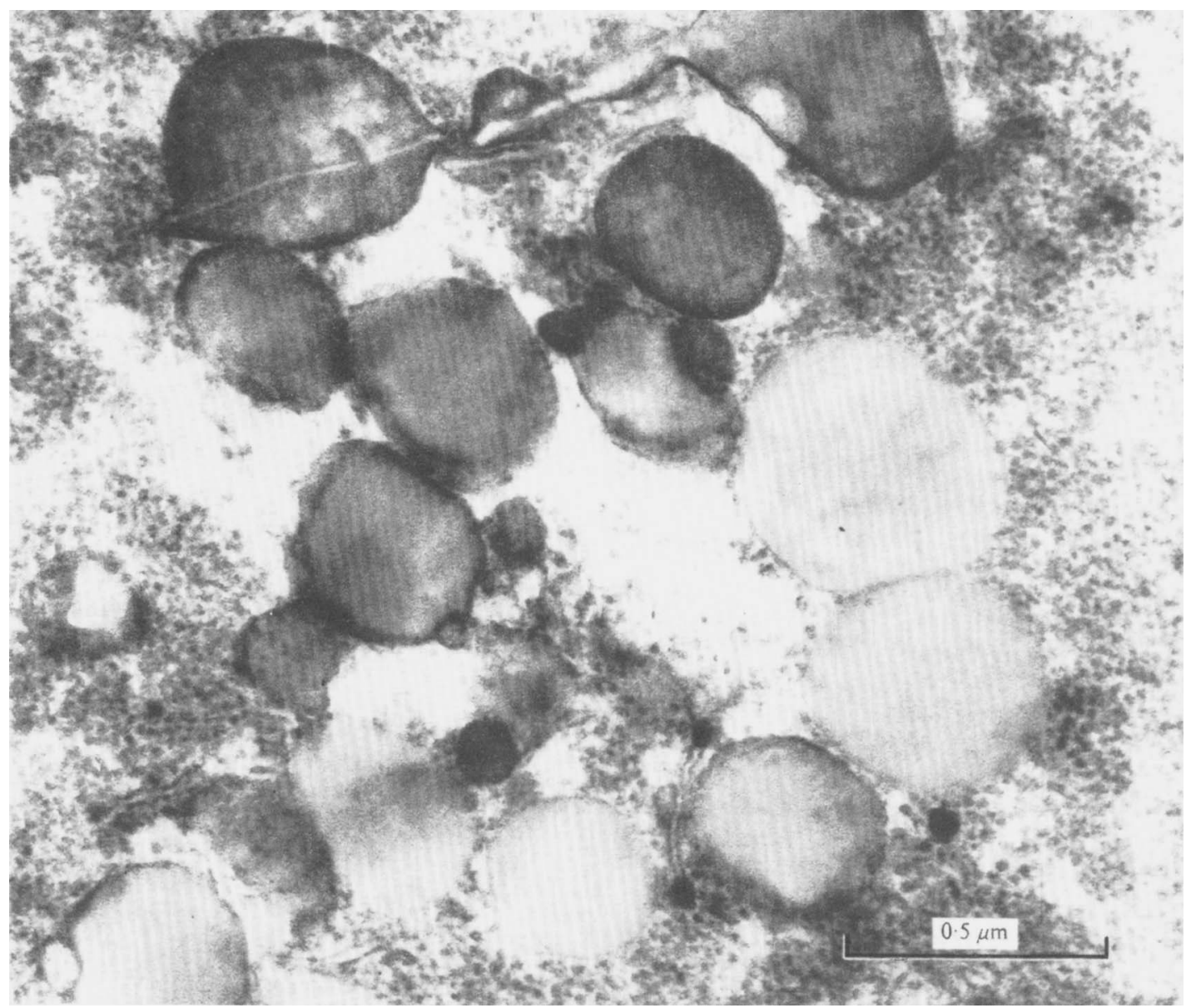

Fig. I. Thin section of a pellet of leaf particles from fractions 17 to 19 of Ficoll density gradients. Counterstained with lead citrate.

Rosebrough, Farr \& Randall (I95I) after precipitation of the protein with 25 vol. of cold acetone.

Inoculation of leaves. Phytophthora infestans was grown on plates of green-bean agar for I week at $15{ }^{\circ} \mathrm{C}$ and sporangia were collected in distilled water. Detached leaves with their petioles in distilled water were lightly sprayed with sporangial suspensions containing $\mathrm{I} \times 10^{1}$ sporangia/ml. Control leaves were sprayed with distilled water. Both inoculated and control leaves were incubated in damp chambers at $20^{\circ} \mathrm{C}$ under natural daylight conditions for $36 \mathrm{~h}$ before sampling, by which time infection showed as numerous discrete lesions up to $\mathrm{I} \mathrm{mm}$ in diam. with about $80 \%$ of the leaf surface remaining green.

Electron microscopy. Particle suspensions derived from density gradients did not survive further sedimentation by centrifugation; consequently suspensions were fixed immediately by the addition of an equal volume of cold $6 \%(\mathrm{w} / \mathrm{v})$ glutaraldehyde in $0 . \mathrm{I} \mathrm{M}$-phosphate buffer, $\mathrm{pH} 7 \cdot 0$, at $4{ }^{\circ} \mathrm{C}$ for $4 \mathrm{~h}$. Suspensions were then centrifuged at $65000 \mathrm{~g}$ for $30 \mathrm{~min}$ at $4{ }^{\circ} \mathrm{C}$, and for routine morphological examinations the pellets were processed for electron microscopy by the procedure of Pitt \& Galpin (I $973 b$ ). 


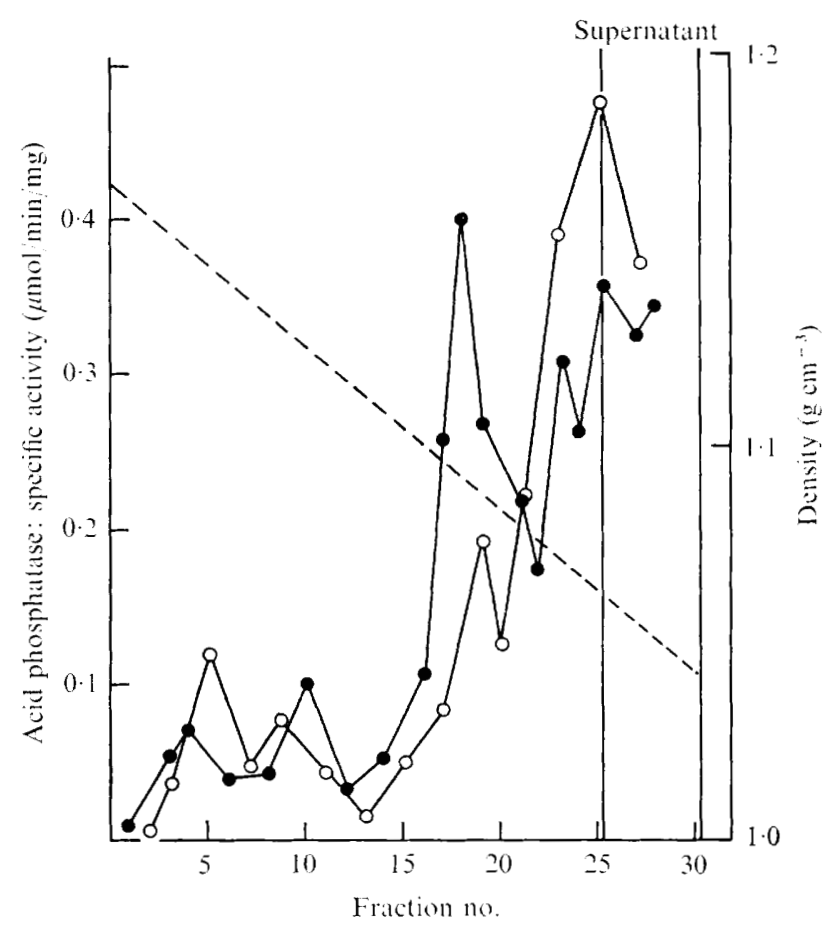

Fig. 2. Distribution of acid phosphatase activity in Ficoll density gradients after ultracentrifugation of normal leaves $(\longrightarrow)$ and infected leaves $(\mathrm{O}-\mathrm{O})$. - - density.

Table I. Solubilization of the acid phosphatase of fraction I8 using various treatments

\begin{tabular}{|c|c|c|c|}
\hline \multirow[b]{2}{*}{ Treatment } & \multicolumn{2}{|c|}{$\begin{array}{l}\text { Activity of enzyme in } \\
\text { fractions }(\%)\end{array}$} & \multirow{2}{*}{$\begin{array}{c}\text { Change in total } \\
\text { activity }(\%)\end{array}$} \\
\hline & Soluble & Particulate & \\
\hline Freeze/thaw & 63.2 & $36 \cdot 8$ & $-15 \cdot 6$ \\
\hline Homogenization & $4 \mathrm{I} \cdot 6$ & $58 \cdot 4$ & $-10 \cdot I$ \\
\hline Ultrasonication & $46 \cdot 0$ & $54 \%$ & -30.5 \\
\hline Triton X-100 & $37 \cdot 7$ & $62 \cdot 3$ & $+20 \cdot 6$ \\
\hline \multicolumn{4}{|l|}{ Osmotic shock } \\
\hline (i) Water & - & - & $-70 \cdot 2$ \\
\hline (ii) Buffer & $75 \cdot 4$ & $24 \cdot 6$ & $-20 \cdot 7$ \\
\hline Venom & $95 \cdot 7$ & $4 \cdot 3$ & $-27 \cdot 0$ \\
\hline Phospholipase A & $33 \cdot 6$ & $66 \cdot 4$ & $-20 \cdot 2$ \\
\hline
\end{tabular}

RESULTS

Properties of isolated particles

Density-gradient ultracentrifugation equilibrated several bands which were examined by electron microscopy. Particles occurring in heavier parts of the gradient (fractions $\mathrm{I}$ to 10 ) were composed primarily of chloroplast debris. The layer of material equilibrating at fractions 17 to 19 was cream-coloured and was largely free from chloroplast components and consisted of a heterogeneous particle population with a size range $0.05 \mu \mathrm{m}$ to $\mathrm{I} \cdot 0 \mu \mathrm{m}$ and a density of $\mathrm{r} .095 \mathrm{~g} \mathrm{~cm}^{-3}$. Some of the particles appeared devoid of membranes but 


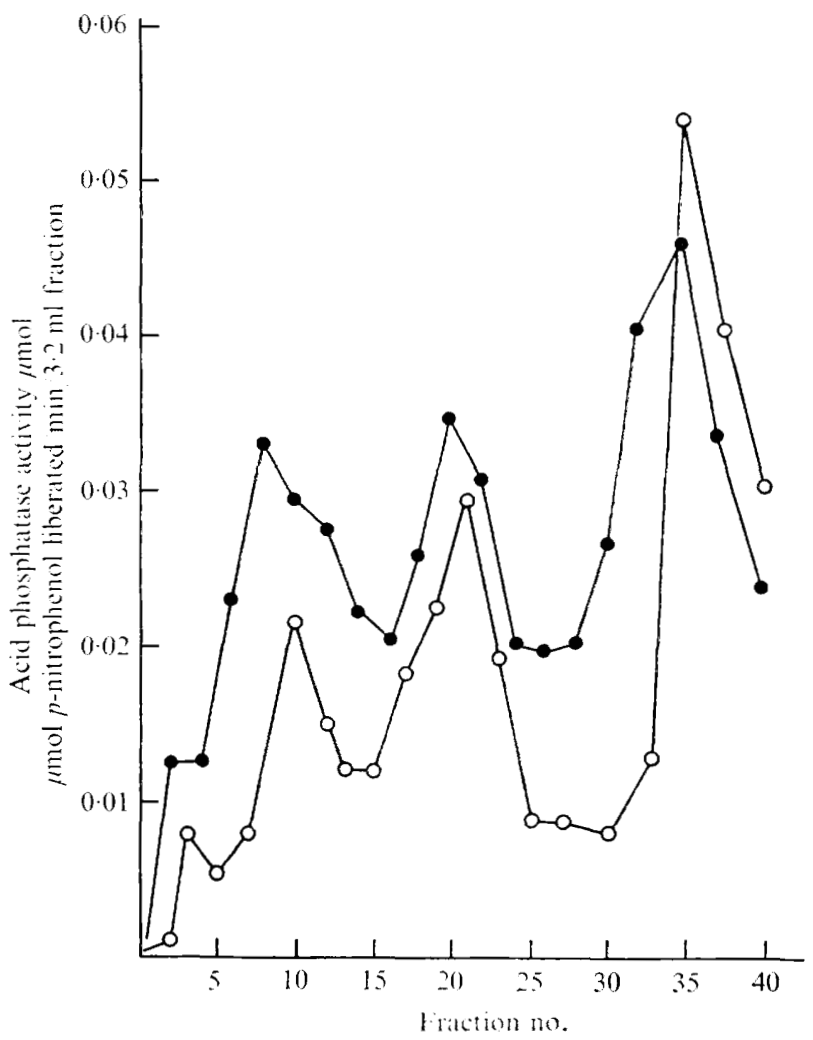

Fig. 3. Molecular forms of acid phosphatase resolved by gel filtration of venom digests of crude lysosomal fractions from healthy leaves $(-\infty)$ and infected leaves $(0-0)$.

others were bounded by single membranes. Double membranes and ER-derived elements and amorphous material were also found (Fig. 1).

Effects of physical factors on the particulate location of acid phosphatase. Assays of fractions for enzyme activity revealed that the major peak of acid phosphatase activity coincided with the distribution of the particulate material equilibrating at fraction 18 during ultracentrifugation. Consequently the effects of physical factors on the stability of this fraction were examined and the results are shown in Table $\mathrm{I}$.

The results in Table I show that all the classical treatments known to liberate acid phosphatase from lysosomes caused release of this enzyme from the particles in fraction I8. Only Triton X-100 gave any appreciable excess-recovery of the enzyme which may be interpreted either as latency or as activation of acid phosphatase which may be achieved in the presence of low concentrations of this detergent (Meany, Gahan \& Maggi, 1967).

\section{Distribution of acid phosphatase in Ficoll density gradients}

Ultracentrifugation of crude lysosomal fractions containing equal amounts of protein derived from healthy and infected leaves resulted in a distribution of acid phosphatase as shown in Fig. 2. Infection was accompanied by a large decrease in activity associated with the particulate fraction and an increase in the non-sedimentable (soluble) activity of acid phosphatase. The total enzyme activity in the crude tissue homogenates derived from both 


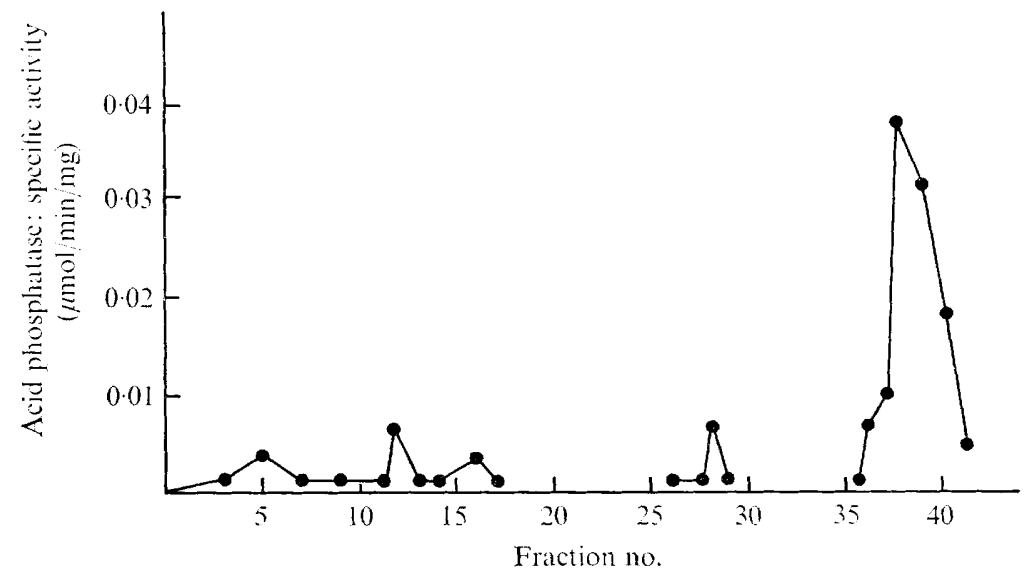

Fig. 4. Molecular forms of acid phosphatase resolved by gel filtration of homogenates of Phytophthora infestans.

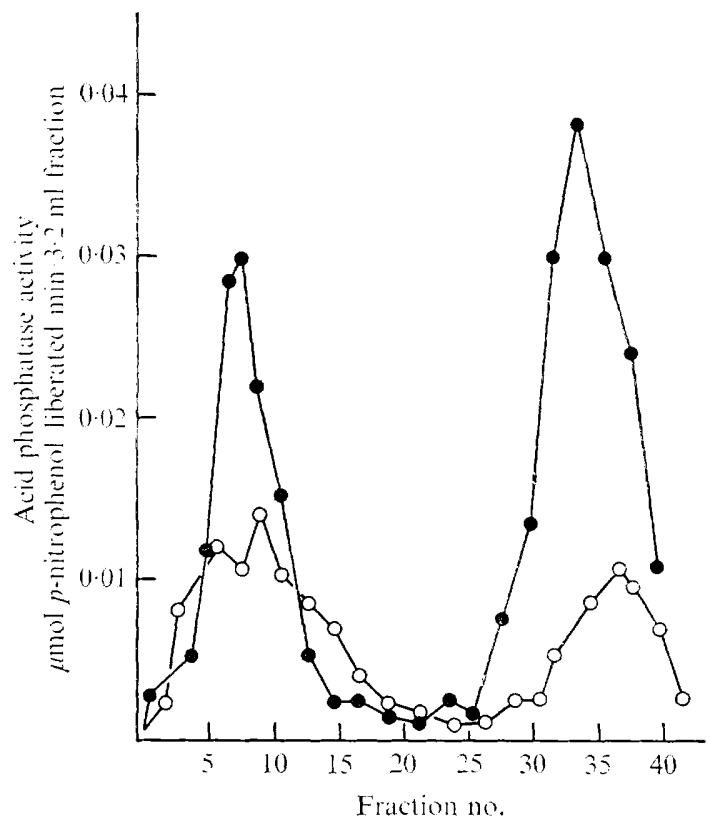

Fig. 5. Molecular forms of acid phosphatase resolved by gel filtration of venom digests of lysosomal fractions (Ficoll density gradient fractions 17 to 19$)$ from healthy leaves (-C) and infected leaves $(\mathrm{O} \longrightarrow \mathrm{O})$.

healthy and infected whole leaves by high-speed maceration were similar. The origin of the increased activity of the soluble enzyme was examined by analysing the molecular forms of acid phosphatase by means of gel filtration techniques.

Molecular forms of acid phosphatase in tissue fractions

Enzyme activity is expressed as units/fraction in the gel filtration experiments in this section. 


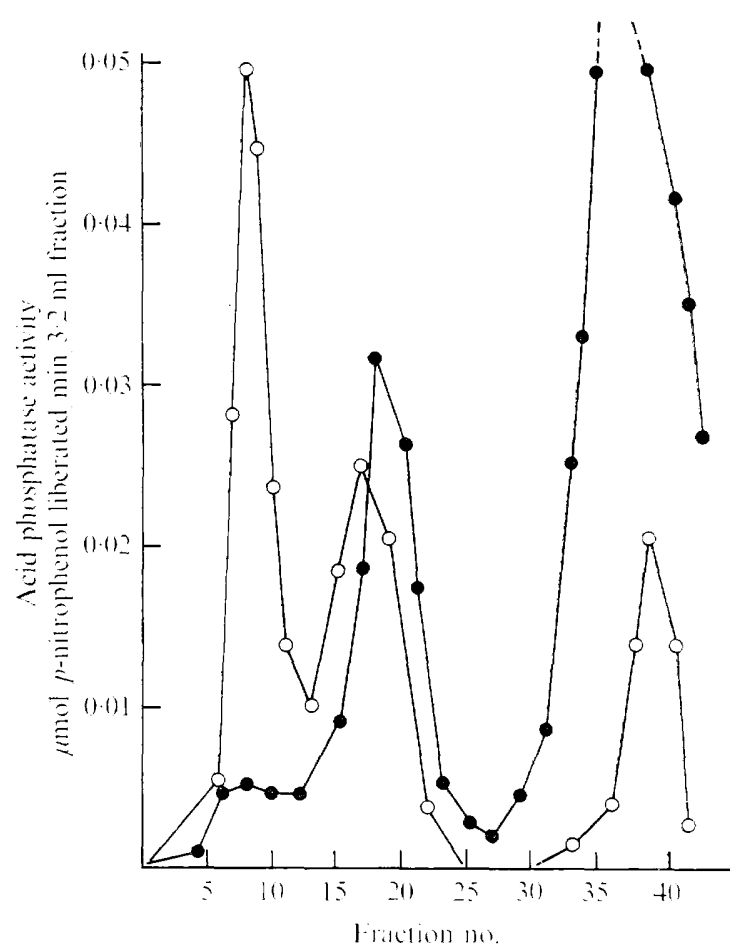

Fig. 6. Molecular forms of acid phosphatase resolved by gel filtration of venom digests of supernatant fluid fractions (soluble enzyme) from healthy leaves $(-0)$ and infected leaves $\left(\mathrm{O}_{-}-\mathrm{O}\right)$.

In crude lysosomal fractions. When crude lysosomal fractions of infected and control leaves were digested with snake venom about $95 \%$ of the acid phosphatase was solubilized. The elution patterns obtained by gel filtration of these digests are shown in Fig. 3. Good recovery of enzyme activity (about $70 \%$ ) was obtained following gel filtration and almost identical elution patterns of the enzyme were obtained with both healthy and infected leaves.

Fig. 4 illustrates the gel-filtration profile of a protein-rich extract of Phytophthora infestans grown for I week on green-bean broth. Only one major peak occurred, which corresponded in position to the peak of low mol. wt arising in digests from lysosomal fractions from leaves. A similar elution pattern was found in fungal homogenates which had been subjected to venom digestion.

In leaf particles from ultracentrifuge gradients. Gel filtration of venom digests of the combined particles isolated in ultracentrifuge gradient fractions 17 to 19 from infected and control leaves revealed two molecular forms of acid phosphatase (Fig. 5). Digests of particle preparations which originally contained equal amounts of particle protein showed major differences: those from infected leaves contained much less acid phosphatase than those from healthy leaves, which suggested that release of particle-bound enzyme may have occurred on infection.

In the soluble phase. The results in Fig. 6 show the quantitative relationships between the three molecular forms of acid phosphatase in the venom digests of the supernatant fluid fractions of healthy and infected leaf tissue extracts that remained at the top of the Ficoll gradients after ultracentrifugation. A massive increase in the peak at fraction 7 was found in 
the infected tissues compared with the uninfected leaves. Some of the activity within the reduced peak at fraction 35 may be derived from the parasite, but a host origin of the peak eluting at fraction 7 is more likely. A peak was virtually absent at fraction 7 in the eluates from healthy tissue which indicated that the extraction procedure led to relatively little damage to host lysosomes. Experiments carried out on supernatant fluid fractions derived by centrifugation at $105000 \mathrm{~g}$ for $30 \mathrm{~min}$ at $4{ }^{\circ} \mathrm{C}$ of crude lysosomal preparations from healthy and infected leaves gave similar results.

\section{Effects of inhibitors of acid phosphatase}

All molecular forms of the enzyme hydrolysing $p$-nitrophenyl phosphate which were eluted during gel filtration experiments were subject to 80 to $90 \%$ inhibition by $\mathrm{NaF}$ (O. I M), L-tartrate (O.I M) and orthophosphate ( $5 \mathrm{mM}$ ). Only slight inhibition was found with ammonium molybdate $\left(\mathrm{IO}^{-5} \mathrm{M}\right)$, which suggested negligible interference from phosphoprotein phosphatase (EC. 3.1.3.16) in the assay for acid phosphatase.

\section{DISCUSSION}

The existence in potato leaves of a heterogeneous population of particles which equilibrated at a density of $\mathrm{I} \cdot 095 \mathrm{~g} \mathrm{~cm}^{-3}$ and from which acid phosphatase could be released by certain characteristic physical treatments suggested that this enzyme was located within bodies possessing affinities with lysosomes. The failure of classical treatments to release fully acid phosphatase from these particles and the necessity for venom digestion to complete the solubilization process indicated that leaf lysosomes may have properties in common with lysosomes from potato sprouts which were considered by Pitt \& Galpin (1973b) to possess acid-phosphatase-binding sites involving phosphatide-ester linkages.

Infection by Phytophthora infestans, which resulted in a decrease in the sedimentable proportion of acid phosphatase accompanied by increased activity in the soluble phase, is in keeping with the earlier findings of Pitt \& Coombes (1969) with potato-callus tissue except that increased total enzyme activity was not found in the leaf experiments. However, the observation in the present work that increased soluble enzyme activity was due to a molecular form of acid phosphatase characteristic of the lysosomes of the healthy host and that the particulate component of the host decreased on infection allows the reasonable assumption that the enzyme arising in the supernatant fluid fraction could have arisen following damage to the host lysosomes. The situation was complicated by the production by the pathogen of a low mol. wt form of acid phosphatase eluting at a position identical to a peak characteristic of the host, and thus it is possible that some of this activity may have been due to secretion by the parasite. A fungal contribution to the increased high mol. wt peak appearing in the supernatant seems unlikely, since this peak was not found in fungal homogenates, but the behaviour of the fungus in the presence of the host cannot be predicted at the present time. Also, infection may have resulted in activation of previously latent lysosomal enzyme as suggested by the results of Pitt \& Galpin (197I) and Pitt (197I) who encountered increased ribonuclease activity after tissue damage to potato tubers and leaves. It cannot be excluded, however, that extralysosomal phosphatase may be synthesized de novo in infected tissues.

In addition it is possible that infection resulted in increased fragility of the host lysosomes, as found in animal tissues by Bitensky (1963), such that subsequent isolation procedures readily disrupted these structures. Such fragility changes are known to be preceded by an altered permeability of the lysosomal membrane, an event which could also permit the entry of an inhibitor of lysosomal acid phosphatase, perhaps of fungal origin, which would 
account for the observed decrease in the particulate enzyme location. Although none of these possibilities can be excluded at present, the earlier histochemical observations (Pitt \& Coombes, I968, I969) have already shown that lysosomal disruption and increased cytoplasmic staining occur during fungal infections of potato tubers.

A reasonable interpretation of the present results, therefore, is that infection results in a redistribution of acid phosphatase without any net change in enzyme activity and involves a release to the soluble phase of the cell of one molecular form of this enzyme that is characteristically membrane-bound in uninfected cells. Similar lines of thought prevail in medicine (de Duve, 1969), but it is not yet known if in any system labilization or destruction of lysosomes is a cause or a consequence of cell death.

I thank the Agricultural Research Council for financial support during this investigation. I also thank Miss Elizabeth Howell for valuable technical help.

\section{REFERENCES}

Bachmann, E., Allmann, D. W. \& Green, D. E. (1966). The membrane systems of the mitochondrion. I. The $\mathrm{S}$ fraction of the outer membrane of beef heart mitochondria. Archives of Biochemistry and Biophysics I15, I 53-164.

BITENSKY, L. (1963). The reversible activation of lysosomes in normal cells and the effects of pathological conditions. In The Lysosomes, pp. 362-375. Edited by A. V. S. de Reuck and M. P. Cameron. London: J. and A. Churchill Ltd.

DE Duve, C. (I969). The lysosome in retrospect. In Frontiers of Biology, no. I4 A. Lysosomes in Biology and Pathology, vol. I, pp. I-40. Edited by J. T. Dingle and H. B. Fell. Amsterdam and London: North Holland Publishing Co.

Ingram, D. S. \& Robertson, N. F. (1965). Interaction between Phytophthora infestans and tissue cultures of Solanum tuberosum. Journal of General Microbiology 40, 43I-437.

Lowry, O. H., Rosebrough, N. J., Farr, J. L. \& Randall, R. J. (I95I). Protein measurement with the Folin phenol reagent. Journal of Biological Chemistry 193, 265-275.

Meany, A., Gahan, P. B. \& Maggi, V. (1967). Effects of Triton X-10o on acid phosphatases with different substrate specificities. Histochemie II, 280-285.

PITT, D. (I97I). Purification of a ribonuclease from potato tubers and its use as an antigen in the immunochemical assay of this protein following tuber damage. Planta, Berlin ror, 333-35I.

PITT, D. \& CoOmbes, C. (1968). The disruption of lysosome-like particles of Solanum tuberosum cells during infection by Phytophthora erythroseptica Pethybr. Journal of General Microbiology 53, 197-204.

PITT, D. \& Coombes, C. (1969). Release of hydrolytic enzymes from cytoplasmic particles of Solanum tuberosum tissues during infection by tuber-rotting fungi. Journal of General Microbiology 56, 32 I-329.

PITT, D. \& GALPIN, M. (I97I). Increase in ribonuclease activity following mechanical damage to leaf and tuber tissues of Solanum tuberosum L. Planta, Berlin ror, 31 7-332.

PITT, D. \& GalPIN, M. (I973a). Role of lysosomal enzymes in pathogenicity. In Fungal Pathogenicity and the Plant's Response. 3rd Long Ashton Symposium. Edited by R. J. W. Byrde and C. V. Cutting. London and New York: Academic Press. (In the Press.)

PITT, D. \& Galpin, M. (1973 b). Isolation and properties of lysosomes from dark-grown potato shoots. Planta, Berlin 109, 233-258. 